Georgia State University

ScholarWorks @ Georgia State University

$1-2-2008$

\title{
Obesity and Time Preference: The Health Consequences of Discounting the Future
}

\author{
Lei Zhange \\ Georgia State University \\ Inas Rashad \\ Georgia State university
}

Follow this and additional works at: https://scholarworks.gsu.edu/uwrg_workingpapers

\section{Recommended Citation}

Zhange, Lei and Rashad, Inas, "Obesity and Time Preference: The Health Consequences of Discounting the Future" (2008). UWRG Working Papers. 4.

https://scholarworks.gsu.edu/uwrg_workingpapers/4

This Article is brought to you for free and open access by the Usery Workplace Research Group at ScholarWorks @ Georgia State University. It has been accepted for inclusion in UWRG Working Papers by an authorized administrator of ScholarWorks @ Georgia State University. For more information, please contact scholarworks@gsu.edu. 
Working Paper 2008-1-2

January 2008

\section{Obesity and Time Preference: The Health Consequences of Discounting the Future}

Lei Zhang

Inas Rashad

Georgia State University 
Obesity and Time Preference: The Health Consequences of Discounting the Future

\author{
Lei Zhang, Doctoral Candidate in Public Administration and Urban Studies \\ Andrew Young School of Policy Studies, Georgia State University \\ Atlanta, GA 30303, USA
}

\author{
Inas Rashad, Assistant Professor of Economics \\ Andrew Young School of Policy Studies, Georgia State University \\ Atlanta, GA 30303, USA
}

Running Heading: Obesity and Time Preference

\begin{abstract}
Summary
Much focus has been placed on the obesity epidemic due to its high prevalence and the costs it imposes on society. Using 2004 data from the Roper Center, complemented with 2003 data from the Behavioral Risk Factor Surveillance System, this study analyzes the possible effect that time preference has on health in the United States, as measured by the body mass index. After controlling for a variety of covariates and correcting for potential selectivity, some evidence of a positive association between time preference for the present and the body mass index can be found, particularly for males. Research in this area has policy implications in terms of creating incentives for those who lack self-control through the use of precommitment devices. Measures addressing self-control issues may be more effective in reducing the rising obesity rates across the world.
\end{abstract}




\section{Obesity and Time Preference: The Health Consequences of Discounting the Future}

\section{Introduction}

The obesity epidemic has been gaining increasing attention as of late because of its high prevalence and the costs it imposes on society. According to the most recent National Health and Nutrition Examination Survey, approximately one third of the American adults are obese, a figure that has doubled in just the past two decades. This rise in obesity prevalence accounted for about 27 percent of the change in health care spending between 1987 and 2002 (Thorpe $e t$ al., 2004). Costs attributed to obesity were estimated to be $\$ 117$ billion as of 2001 (USDHHS, 2001), a figure that reflects both direct costs, such as expenditures on medical services and weight-loss drugs, and indirect costs, such as lost wages due to missing work because of obesity-related illnesses and early retirement.

Several hypotheses have been put forth regarding the root causes of obesity. It is generally understood that obesity results from a combination of excess caloric intake and physical inactivity. However, behavioral responses leading to the overconsumption of food and the adoption of a sedentary lifestyle have yet to be carefully analyzed, and a previous article in this journal stressed that "currently there is not sufficient evidence to rigorously test the role of time preference [for the present] in the obesity epidemic" (Komlos et al. 2004, p210). Cutler et al. (2003) suggest that reductions in the time cost of food preparation due to technological change have increased the immediate consumption value of food relative to the long-term health costs. Pointing to the role of self-control, they attribute the difficulty individuals have passing up current pleasure for future benefits as a significant factor in the rise in obesity rates in recent decades. They go on to say that those with self-control problems are more likely to have high initial weight levels and are more likely to gain more weight with improvements in food 
technology. As Chou et al. (2004) also assert, reductions in the time cost of food have a large effect on the level of obesity, and thus focus should be placed on that in addition to the monetary cost of food.

Lakdawalla \& Philipson (2002) have found that reductions in the strenuousness of work and declines in the real price of grocery food items (largely due to technological advances in agriculture) have been key factors in causing the rise in obesity. The increasing obesity rate has also been attributed to the increased prevalence of fast-food and full-service restaurants and their reduced prices, as well as the unintended effect of the campaign on smoking (through numerous cigarette excise taxes and clean indoor air laws intended to discourage cigarette smoking) (Chou et al., 2004; Rashad et al., 2006). Ewing et al. (2003) use a comprehensive measure of urban sprawl that takes into account residential density, land use mix, degree of centering and street accessibility, and measures how conducive a city is to exercise. They find a positive association between the degree of urban sprawl and obesity in a metropolitan statistical area.

To study the determinants of obesity as well as the mechanisms involved, this study employs the 2004 Roper Center Obesity survey data. The findings using these data are complemented using a more widely used data set, the 2003 Behavioral Risk Factor Surveillence System (BRFSS). The advantage of the Roper Center data is the availability of detailed questions on attitudes and behavior regarding weight control, particularly concerning lacking the willpower to lose weight. While no comparable variables exist in the BRFSS data set in 2004, the variable "trying to lose weight" from the 2003 BRFSS is combined with questions on actual weight and desired weight. A dichotomous variable, "desire but no effort," was created that equals 1 if the respondent desires to weigh at least five pounds less than his or her current weight (approximately 2.27 kilograms) and yet did not report trying to lose weight. Although this 
variable is not the same as the "lacking willpower" variable available in the Roper Center data, it is the closest using a large data set conducted by the Centers for Disease Control.

There may be some concern about the self-reported nature of the anthropometric data, gathered through telephone surveys. The bias from the use of self-reported data in this context tends to be minimal. Using data from the National Health and Nutrition Examination Survey, which contains both objective and subjective measures, studies have shown error in self-reported weight and height to be negligible except when analyzing population subgroups (Rowland, 1990; Niedhammer et al., 2000; Gillum and Sempos, 2005). Previous work using adjusted measures has revealed little difference in the resulting coefficients (Rashad, 2006). For the purposes of this paper, where the focus is on predicting outcomes and identifying relationships, rather than obtaining prevalence estimates, self-reported data are likely to be reliable (Bolton-Smith et al., 2000; Kuczmarski et al., 2001; Spencer et al., 2002).

The Roper Center data offer recent anthropometric information on individuals in the United States, and also provide their users with a variety of variables pertaining to attitudes surrounding weight. Obesity is measured using the body mass index (BMI), defined as weight in kilograms divided by height in meters squared. According to the National Institutes of Health, an obese adult is defined as one having a BMI of $30 \mathrm{~kg} / \mathrm{m}^{2}$ or greater, while an overweight adult is defined as one having a BMI greater than or equal to $25 \mathrm{~kg} / \mathrm{m}^{2}$. While not necessarily the best measure, the BMI is convenient as it is routinely measured in physical examinations and is widely used in measuring obesity. Some evidence of a positive association between time preference for the present and BMI is found. Males in particular are responsive to changes in time preference. In addition, time preference for the present may place men at a higher risk for 
obesity. A variety of covariates are controlled for, including marital status, education, age, race, ethnicity, and residence in an urban area.

\section{Background and Literature Review}

Time preference is frequently referred to as "the preference for immediate utility [satisfaction or happiness one gets through consuming a good] over delayed utility" (Frederick et al., 2002). A low rate of time preference is an indicator that an individual is patient and has self-control, or does not discount the future heavily, while having a high rate of time preference means that an individual places more emphasis on the present and discounts the future relatively heavily. The relationship between time preference and obesity is potentially important because an individual's intertemporal choice could be the ultimate culprit of most behaviors that lead to obesity (for example, adopting a sedative lifestyle or eating compulsively). For instance, most weight control methods require one to forgo current consumption of unhealthy foods in order to reap future health gains. A strong preference for immediate gratification given by French fries, for example, over delayed health benefits could make a person more susceptible to weight gain.

Focusing on the relationship between time preference and obesity also has policy relevance. A strong tie between one's weight and time preference might cause us to question whether the current obesity prevention and intervention programs are adequate in curbing this epidemic. Policies that aim at educating people to be more future-oriented, or providing incentives for them to use pre-commitment devices, might yield higher returns to current investment.

A few studies have investigated the link between time preference and obesity. One such study is that of Komlos et al. (2004). Using aggregate data, they find that from the 1970s to the 
1990s, the trend in private consumer debt, a high level of which might be indicative of a high rate of time preference, corresponds with the rising obesity rate. The personal savings rate, on the other hand, falls as the obesity rate increases. The Komlos et al. (2004) study is helpful in addressing the possible connection between obesity and time preference. One shortcoming, however, is that it only makes use of aggregate data and fails to control for a variety of other factors that may be responsible for this rising pattern in obesity.

Using two years of data (1981 and 1989) on young Americans from the National Longitudinal Survey of Youth, Smith et al. (2005) examine individuals and their BMIs as a function of family income, age, ethnicity, and proxies for time preference (changes in respondents' savings levels between 1981 and 1989). They find a positive association between these proxies and BMI among black and Hispanic men, and black women. Although their results are consistent with those of Komlos et al. (2004), the validity of the authors' measure of time preference is highly questionable. Changes in the savings level may depend on many factors other than one's time preference. Furthermore, there is no sound theoretical evidence that savings alone can capture an individual's rate of time preference.

Most of the literature on intertemporal choice primarily relies on two approaches to measure time preference. One is to infer a discount factor from an individual's consumption in different periods (see, for example, Lawrance, 1991; Bernheim et al., 2001; Dynan et al., 2004). As outlined in Komlos et al. (2004), the intertemporal discount rate $(1 /(1+\sigma))$ can be used to measure the present value of future utility, or happiness one gets through consuming a good. If $\sigma$ is equal to zero, the intertemporal discount rate is equal to 1 , meaning that the individual places equal value on both present and future consumption of a good. The higher $\sigma$ is, the less weight the individual places on future consumption of the good. Studies identifying a subjective 
rate of time preference estimate consumption Euler equations that require strict assumptions assumptions that are often violated in reality. For example, one of the assumptions states that $\sigma$ is not only constant over time but also uniform across all consumption categories. However, empirically observed discount rates suggest that $\sigma$ is smaller over long time horizons than short time horizons - evidence of hyperbolic discounting (Thaler, 1981; Redelmeier \& Heller, 1993; Chapman, 1996). (There has been a recent interest in the concept of hyperbolic discounting in the behavioral economics literature. This term differs from regular discounting in that the person particularly values imminent gratification, and does not largely distinguish between gratification in the near and far futures.) Studies also show that this pattern fits data better than constant discounting (Myerson \& Green, 1995; Kirby, 1997; Bishai, 2004). Furthermore, there is empirical evidence that $\sigma$ is not identical when applied to different sources of utility. For example, Chapman \& Coups (1999) demonstrate that rates of time preference are not consistent across multiple health domains. In addition to the problematic assumptions, time preference estimates obtained from this approach are sensitive to the interest rate employed in the calculation. Lawrance (1991) provides evidence that using a passbook savings rate produces a substantially lower $\sigma$ than using a Treasury bill rate.

A second approach presents respondents with hypothetical questions involving intertemporal choices (Fuchs, 1982; Chapman, 1996; Chapman \& Coups, 1999; Chapman et al., 1999; Chesson \& Viscusi, 2000). Some studies estimate the respondents' implied discount rates by asking them to choose between receiving a payment or fine now or receiving one in the future; others ask participants to choose between an immediate sum amount of money and a delayed, larger amount under different circumstances. The validity of this approach has been questioned because the imputation of $\sigma$ is subject to how the questions are phrased (Benzion et al., 1989). 
A key drawback of using a single discount rate to gauge an individual's rate of time preference is its failure to capture the fundamental psychological motives that the concept originally attempts to measure (Frederick et al., 2002). It is fundamental to understand that what this discount rate in fact predicts is money-related behavior, such as carrying savings or debt (Lawrance, 1991; Bernheim et al., 2001; Dynan et al., 2004). This is partly why little evidence has been found of a correlation between $\sigma$ and other real world behavioral expressions thought to reflect time preference (Chapman \& Elstein, 1995; Chapman et al., 2001). To obtain an understanding of the correlation between time preference and intertemporal behavior, especially that related to lifestyle choices such as eating and exercising, the rates of time preference based on a person's specific motives need to be disentangled. A person may discount the future heavily when it comes to one thing, and yet not discount it when it comes to another. Loewenstein et al. (2001) propose three constituents: impulsivity (defined as "the degree to which an individual acts in a spontaneous, unplanned fashion"), compulsivity (defined as "the tendency to make plans and stick with them"), and inhibition (defined as "the ability to inhibit automatic response to the appetites and emotions that trigger impulsive behavior"), all of which could be considered as individuals exerting an inner force (power of will) to override some type of underlying motivation. As suggested by Loewenstein (2000), exertions of willpower always involve sacrifices of immediate utility for the sake of future benefits. For example, willpower is used to suppress a desire for high-calorie food when it is easily accessible, and to avoid indulgence in the instant satisfaction of doing something else other than exercise. Hence, individuals who want to lose weight but lack the willpower will find it more difficult to stick to their diet and exercise plans, leaving them at a higher risk for obesity. That being said, this 
variable is also an imperfect measure of time preference, as the variable "lacking willpower" could be capturing other factors that are unobservable.

\section{Data and Estimation Methods}

To investigate the relationship between time preference and obesity, this paper employs the 2004 Obesity Poll, a telephone survey conducted by the Roper Center for Public Opinion Research. The original sample consists of a random draw of 1,202 nationally representative adults (18 years of age and older) from the U.S. population. Summary statistics for the whole sample are reported in Table 1a, by obese status. Looking at these means reveals that high school graduates and black non-Hispanic individuals are significantly more likely to be obese, while college graduates and those with higher incomes are significantly less likely to be obese. Means from the larger BRFSS data set (not shown) are comparable, giving confidence in the random nature of the Roper Center data. The Behavioral Risk Factor Surveillance System (BRFSS) is an individual-level data set put together by state health departments in conjunction with the Centers for Disease Control and Prevention. It is conducted annually through telephone surveys and includes all 50 states in addition to the District of Columbia. The BRFSS asks numerous health questions, including questions on general health status, weight, and height, in addition to detailed demographic data.

The Roper Center data are appropriate for this study due to the survey questions asked of respondents. These data allow for the utilization of willpower as an indicator of time preference, a measure based on the question asking the respondent whether or not lack of willpower is the greatest barrier to weight control. However, it is only asked of those individuals who indicate that they would like to lose weight. Among those who want to lose weight, approximately 40 
percent indicate that the main reason that they find it difficult to lose weight is not having the willpower to do so (Table 1b). A closer look at this sample reveals that those who are overweight (in this case, having a BMI greater than or equal to $25 \mathrm{~kg} / \mathrm{m}^{2}$ but less than $30 \mathrm{~kg} / \mathrm{m}^{2}$ ) or obese are more likely to want to lose weight than their slimmer counterparts, yet 41 percent of those of normal weight, and 7 percent of those who are underweight, would also like to lose weight, as revealed in Figure 1. Of those wanting to lose weight, 43 percent of those who are overweight and 42 percent of those who are obese are experiencing difficulty in self-control, or lack the willpower to stick to their weight control plans (Figure 2). These numbers suggest that one the greatest barriers for overweight and obese persons in controlling their weight might be more intrinsic rather than extrinsic.

To test this hypothesis, the following model is estimated:

$$
B M I_{i}=\beta_{0}+\beta_{1} \text { willpower }_{i}+\beta_{2} X_{i}+\varepsilon_{1 i},
$$

where $B M I$ represents a respondent's body mass index, willpower is a dichotomous variable indicating the individual's lack of willpower, and $i$ indexes the individual. A set of demographic characteristics $(X)$ is included to capture the influence that other variables might have on an individual's BMI. Cutler et al. (2003) argue that reductions in the time cost of food preparation have increased the immediate consumption value of food relative to the long-term health costs; hence those with self-control problems tend to consume more than the optimal amount of food. Ceteris paribus, it is expected that those who lack willpower to be heavier because they are more likely to be frequent diners in fast-food restaurants, where both the time and monetary costs of food consumption are low.

Although this survey provides information on obesity and weight attitudes, its limitation lies in that the data are censored due to filtering. The willpower question, the key variable of 
interest, is asked only if the respondent indicates that he or she would like to lose weight in a previous question. Selectivity issues thus arise due to the possible nonrandom nature of the resulting data. In line with Heckman (1979), the following treatment equation is given because equation (1) above is restricted to those who are trying to lose weight (a selected sample):

$$
\text { Loseweight }_{i}=1\left(\gamma_{0}+\gamma_{1} Z_{i}+\gamma_{2} X_{i}+\varepsilon_{0 i}>0\right)
$$

where $Z$ indicates excluded variables (whether the respondent is in favor of a law requiring restaurants to list calorie and fat content, and whether the respondent is in favor of a law setting a legal limit on portion sizes in restaurants), variables that are included in the treatment equation but not in the BMI equation. An individual's interest in weight control is a function of support for these laws, but this support does not determine BMI. Hausman tests that examine the validity of ordinary least squares (OLS) regressions reveal their reliability - that selection is not an issue in this case. We therefore report results from OLS regressions.

\section{Results}

Table 2 presents whole sample regression results for the Roper Center (columns 1 and 2) and BRFSS (columns 3 and 4) data sets. Almost half of the data in column 2 are censored, yielding 555 uncensored observations. Compared with those who do not have a problem with self-control, those who lack willpower are found to be slightly heavier, exhibiting an increase in body mass index of $0.502 \mathrm{~kg} / \mathrm{m}^{2}$, ceteris paribus (although the coefficient on willpower is not statistically significant). This is consistent with what Fuchs (1991) found in his investigation of the connection between time preference and health, where a weak relationship is reported. In column 4, desiring to weigh less yet not making the effort to lose weight is associated with an increase in BMI of $0.691 \mathrm{~kg} / \mathrm{m}^{2}$. Lower education categories are positively associated with BMI, 
while higher categories (those who have had at least a college education) are negatively associated with BMI, with those who have elementary or less education as the reference group. (The highest level of education reported in the BRFSS is graduation from college.) This result is in line with some of the research which predicts a negative effect of education on health (see, for example, Grossman, 2005). While income does not seem to have an effect in the Roper Center, its sign is negative, as expected, and significant in the BRFSS data. The coefficient on the urban variable is negative, verifying the slimmer nature of urban dweller as compared with their rural counterparts. Age and male gender are positively correlated with BMI, as is being of a race/ethnicity other than white non-Hispanic.

For comparison purposes, the model is estimated without the willpower variable, as seen in columns 1 and 3 . Column 1 has more observations than column 2 as it includes the censored sample (that does not answer the willpower question).

Table 3 shows regression results for men and women separately. For women, there is no evidence that BMI is related to time preference, as measured by lack of willpower. However, for men, those who struggle with willpower have a BMI that is about $1.17 \mathrm{~kg} / \mathrm{m}^{2}$ higher than those who do not lack willpower. Interestingly, if "desire but no effort" is used as a proxy for time preference in this context, a significant effect can be seen for both males and females, although the magnitude for males is much higher than that for females (an increase of $1.15 \mathrm{~kg} / \mathrm{m}^{2}$ as opposed to $0.32 \mathrm{~kg} / \mathrm{m}^{2}$ ).

To further examine the association between time preference and obesity, a probit model is run using the same set of independent variables, but with a dependent variable equal to 1 if the respondent is obese $\left(\mathrm{BMI} \geq 30 \mathrm{~kg} / \mathrm{m}^{2}\right)$ and 0 otherwise. Results for the whole sample are reported in Table 4. A significant relationship between time preference and obesity cannot be 
found in this case when the "lack of willpower" variable is used. However, when the model is estimated separately by gender, results of which are shown in Table 5, a significant impact of time preference for men is again found: Those who lack willpower are more likely than those who do not to be obese. A surprising finding in this table is that females in the BRFSS sample are significantly less likely to be obese if they would like to weigh less yet are not trying to lose weight. This may be partly understood by noting that a larger percentage of females than males wish to weigh less even if they are not (and are aware that they are not) overweight or obese.

Since there is much in the literature on the importance of self-perception of weight, a variable available to us in this rich cross-sectional data set, Figure 3 shows how self-perception of weight varies within actual weight category. This figure reveals that four percent of those who are underweight in this data set believe they are somewhat or very overweight, and approximately 11 percent of those of normal weight believe they are somewhat or very overweight. On the other hand, almost 20 percent of those who are obese do not believe they are even somewhat overweight, and almost 45 percent of those who are overweight perceive themselves as being of normal weight.

\section{Discussion}

Results from this analysis support the hypothesis that time preference has a significant impact on BMI and the probability of being obese. Men in particular are more susceptible if they lack willpower. This finding is consistent with what Smith et al. (2005) find using a different measure for time preference. They report that their proxies for a higher rate of time preference are strongly associated with male BMI and to a lesser extent with female BMI. This gender difference in the effect of BMI and obesity may relate to different attitudes toward body image 
among men and women. Ideal male images are often depicted as strong and muscular, whereas flawless female figures are usually slender and fit. Given these perceptions of ideal body sizes, it is plausible that women would be more motivated to exercise self-control since their perceived future benefits from it outweigh current costs. Note that the focus here is on willpower. Recent statistics given by the Centers for Disease Control show higher rates of obesity for women compared to those of men; this is likely due to reasons other than willpower.

One implication for the current policy of obesity control is that in addition to providing the public with necessary information about nutritional facts, policies should create incentives for those who lack self-control to use pre-commitment devices. For example, dieting programs which are closely monitored by health coaches can be very effective for those who lack willpower. Similarly, the government could fund programs that motivate people to choose healthy lifestyles such as investing in paving sidewalks so that cycling to work or school becomes more appealing. Other means of changing rates of time preference include educational programs to change people from being myopic to becoming more far-sighted. However, this study does not suggest that those who claim to lack willpower are necessarily irrational, although this interpretation of time preference and hyperbolic discounting has been suggested by some. While individuals may regret their actions at a later time, they may think rationally at the moment of their actions - maximizing current utility - and simply discount the future heavily. Those who lack self-control thus discount the future more heavily than others. Additional policies to discourage discounting the future heavily have been looked at; the literature on selfcontrol has developed extended discussions for decades on ways to educate children to be more patient (for example, by saving money in piggy banks) (Thaler \& Shefrin, 1981). 
This paper has some limitations. The current study assumes that there is no reverse causality going from BMI to time preference. It is plausible to assume that one's body weight does not have an effect on his or her time preference, although Becker \& Mulligan (1997) posit that health status may determine the level of time preference. All of their evidence, however, assumes that consumption growth is a valid indicator of time preference. As is argued in this paper, this assumption may need reexamination. Furthermore, there is no evidence suggesting that obesity has an impact on time preference. Future studies should focus on employing larger data sets and applying valid instruments to allow for the endogeneity of time preference, as unobserved variables may exist that jointly determine obesity and time preference. 


\section{References}

Becker, G. S. \& Mulligan, C. B. (1997) The endogenous determination of time preference. Quarterly Journal of Economics 112, 729-758.

Benzion, U., Rapoport, A. \& Yagil, J. (1989) Discount rates inferred from decisions - an experimental study. Management Science 35, 270-284.

Bernheim, B. D., Jonathan, S. \& Steven, W. (2001) What accounts for the variation in retirement wealth among U.S. households? American Economic Review 91, 832-857.

Bishai, D. M. (2004) Does time preference change with age? Journal of Population Economics 17, 583-602.

Bolton-Smith C., Woodward M., Tunstall-Pedoe H., \& Morrison C. (2000) Accuracy of the estimated prevalence of obesity from self reported height and weight in an adult Scottish population J Epidemiol Community Health 54, 143-148.

Chapman, G. B. \& Coups, E. J. (1999) Time preferences and preventive health behavior: acceptance of the influenza vaccine. Medical Decision Making 19, 307-314.

Chapman, G. B. \& Elstein, A. S. (1995) Valuing the future: temporal discounting of health and money. Medical Decision Making 15, 373-386.

Chapman, G. B. (1996) Temporal discounting and utility for health and money. Journal of Experimental Psychology-Learning Memory and Cognition 22, 771-791.

Chapman, G. B., Brewer, N. T., Coups, E. J., Brownlee, S., Leventhal, H. \& Leventhal, E. A. (2001) Value for the future and preventive health behavior. Journal of Experimental Psychology-Applied 7, 235-250.

Chapman, G. B., Nelson, R. \& Hier, D. B. (1999) Familiarity and time preferences: decision making about treatments for migraine headaches and Crohn's disease. Journal of Experimental Psychology-Applied 5, 17-34.

Chesson, H. \& Viscusi, W. K. (2000) The heterogeneity of time-risk tradeoffs. Journal of Behavioral Decision Making 13, 251-258.

Chou, S., Grossman, M. \& Saffer, H. (2004) An economic analysis of adult obesity: results from the Behavioral Risk Factor Surveillance System. Journal of Health Economics 23, 565-587.

Cutler, D. M., Glaeser, E. L. \& Shapiro, J. M. (2003) Why have Americans become more obese? Journal of Economic Perspectives 17, 93-118.

Dynan, E. K., Skinner, J. \& Zeldes, P. S. (2004) Do the rich save more? Journal of Political Economy 112, 397-444. 
Ewing, R., Schmid T, Killingsworth, R., Zlot, A. \& Raudenbush, S. (2003) Relationship between urban sprawl and physical activity, obesity, and morbidity. American Journal of Health Promotion 18, 47-57.

Frederick, S., Loewenstein, G. \& O'Donoghue, T. (2002) Time discounting and time preference: a critical review. Journal of Economic Literature 40, 351-401.

Fuchs, V. (ed) (1982) Economic Aspects of Health. Chicago: University of Chicago Press.

Gillum R.F. \& Sempos C.T. (2005) Ethnic variation in validity of classification of overweight and obesity using self-reported weight and height in American women and men: the Third National Health and Nutrition Examination Survey Nutr J 6, 27.

Grossman, M. (2005) Investing In Health by Investing In Schooling. Presented at the Fifth World Congress of the International Health Economics Association, Barcelona, Spain.

Heckman, J. J. (1979). Sample selection bias as a specification error. Econometrica 47, 153-161.

Kirby, K. N. (1997) Bidding on the future: evidence against normative discounting of delayed rewards. Journal of Experimental Psychology-General 126, 54-70.

Komlos, J., Smith, P. \& Bogin, B. (2004) Obesity and the rate of time preference: is there a connection? Journal of Biosocial Science 36, 209-219.

Kuczmarski M.F., Kuczmarski R.J., \& Najjar M. (2001) Effects of age on validity of selfreported height, weight, and body mass index: findings from the Third National Health and Nutrition Examination Survey, 1988-1994 J Am Diet Assoc 101, 28-34.

Lakdawalla, D. \& Philipson, T. (2002) The growth of obesity and technological change: a theoretical and empirical examination. NBER Working Paper No. 894.

Lawrance, E. C. (1991) Poverty and the rate of time preference: evidence from panel data. Journal of Political Economy 99, 54-77.

Loewenstein, G. (2000) Willpower: a decision-theorist's perspective. Law and Philosophy 19, 51-76.

Loewenstein, G., Weber, R., Flory, J., Manuck, S. \& Muldoon, M. (2001) Dimensions of time discounting. Presented at the Survey Research on Household Expectations and Preferences, Ann Arbor, MI.

Myerson, J. \& Green, L. (1995) Discounting of delayed rewards - models of individual choice. Journal of the Experimental Analysis of Behavior 64, 263-276.

Niedhammer I., Bugel I., Bonenfant S., Goldberg M., \& Leclerc A. (2000) Validity of selfreported weight and height in the French GAZEL cohort. International Journal of Obesity and Related Metabolic Disorders 24, 1111-1118. 
Rashad, I. (2006) Structural estimation of caloric intake, exercise, smoking, and obesity. Quarterly Review of Economics and Finance, 46, 268-283.

Rashad, I., Grossman, M. \& Chou, S. (2006) The super size of America: an economic estimation of body mass index and obesity in adults. Eastern Economic Journal 32, 133148.

Redelmeier, D. A. \& Heller, D. N. (1993) Time preference in medical decision-making and cost-effectiveness analysis. Medical Decision Making 13, 212-217.

Rowland M.L. (1990) Self-reported weight and height. American Journal of Clinical Nutrition 52, 1125-1133.

Smith, P. K., Bogin, B. \& Bishai, D. (2005) Are time preference and body mass index associated? Evidence from the National Longitudinal Survey of Youth. Economics and Human Biology 3, 259-270.

Spencer E.A., Appleby P.N., Davey G.K., \& Key T.J. (2002) Validity of self-reported height and weight in 4808 EPIC-Oxford participants Public Health Nutr 5, 561-565.

Thaler, R. (1981) Some empirical evidence on dynamic inconsistency. Economics Letters $\mathbf{8}$, 201-207.

Thaler, R. H. \& Shefrin, H. M. (1981) An economic theory of self-control. Journal of Political Economy 89, 392-406.

Thorpe, K. E., Florence, C. S., Howard, D. H. \& Joski, P. (2004) The impact of obesity on rising medical spending. Health Affairs Suppl Web Exclusives W4, 480-486.

US Department of Health and Human Services (2001) The Surgeon General's Call to Action to Prevent and Decrease Overweight and Obesity. Washington DC: US Government Printing Office. 
Table 1a

Summary Statistics, Roper Center Data

\begin{tabular}{|c|c|c|c|}
\hline Variable & Definition & Obese & Non-Obese \\
\hline $\begin{array}{l}\text { Body mass } \\
\text { index }\end{array}$ & Weight in kilograms divided by height in meters squared & $34.853^{\prime}$ & 24.405 \\
\hline Obese & $\begin{array}{l}\text { Dichotomous variable that equals } 1 \text { if } \mathrm{BMI} \text { is equal to or greater } \\
\text { than } 30 \mathrm{~kg} / \mathrm{m}^{2}\end{array}$ & $1.000^{\prime}$ & 0.000 \\
\hline Willpower & $\begin{array}{l}\text { Dichotomous variable that equals } 1 \text { if respondent finds having } \\
\text { willpower difficult and equals } 0 \text { otherwise }\end{array}$ & 0.427 & 0.415 \\
\hline Married & Dichotomous variable that equals 1 if respondent is married & 0.558 & 0.635 \\
\hline Divorced & $\begin{array}{l}\text { Dichotomous variable that equals } 1 \text { if respondent is divorced or } \\
\text { separated }\end{array}$ & 0.164 & 0.128 \\
\hline Widowed & Dichotomous variable that equals 1 if respondent is widowed & 0.073 & 0.047 \\
\hline Male & Dichotomous variable that equals 1 if respondent is male & 0.491 & 0.488 \\
\hline $\begin{array}{l}\text { Some high } \\
\text { school }\end{array}$ & $\begin{array}{l}\text { Dichotomous variable that equals } 1 \text { if respondent completed at } \\
\text { least } 9 \text { years but less than } 12 \text { years of schooling }\end{array}$ & 0.085 & 0.061 \\
\hline $\begin{array}{l}\text { High school } \\
\text { graduate }\end{array}$ & $\begin{array}{l}\text { Dichotomous variable that equals } 1 \text { if respondent completed } \\
\text { exactly } 12 \text { years of formal schooling }\end{array}$ & $0.382^{\prime}$ & 0.257 \\
\hline Some college & $\begin{array}{l}\text { Dichotomous variable that equals } 1 \text { if respondent completed at } \\
\text { least } 13 \text { years but less than } 16 \text { years of formal schooling }\end{array}$ & 0.285 & 0.283 \\
\hline College & $\begin{array}{l}\text { Dichotomous variable that equals } 1 \text { if respondent completed } \\
\text { exactly } 16 \text { years of formal schooling }\end{array}$ & $0.170^{\prime}$ & 0.268 \\
\hline College plus & $\begin{array}{l}\text { Dichotomous variable that equals } 1 \text { if respondent has more than } \\
\text { college education }\end{array}$ & $0.061^{\prime}$ & 0.118 \\
\hline Age & Age of respondent & $47.158^{\prime}$ & 44.968 \\
\hline Income & Household income in thousands of dollars & $61.864^{\prime}$ & 74.029 \\
\hline White & $\begin{array}{l}\text { Dichotomous variable that equals } 1 \text { if respondent is white but not } \\
\text { Hispanic }\end{array}$ & 0.127 & 0.071 \\
\hline Black & $\begin{array}{l}\text { Dichotomous variable that equals } 1 \text { if respondent is black but not } \\
\text { Hispanic }\end{array}$ & $0.067^{\prime}$ & 0.045 \\
\hline Hispanic & Dichotomous variable that equals 1 if respondent is Hispanic & 0.061 & 0.066 \\
\hline Other & $\begin{array}{l}\text { Dichotomous variable that equals } 1 \text { if respondent's race other than } \\
\text { white, black, or Hispanic }\end{array}$ & 0.473 & 0.520 \\
\hline Urban & $\begin{array}{l}\text { Dichotomous variable that equals } 1 \text { if respondent lives in a large } \\
\text { city or suburb, and equals } 0 \text { if respondent lives in a small town or } \\
\text { a rural area }\end{array}$ & 34.853 & 24.405 \\
\hline
\end{tabular}

Note: Sample size is 979. A slash denotes that the difference between the obese and the non-obese for the given variable is statistically significant at the five percent level. 
Table 1b

\section{Breakdown for Question on Willpower}

\begin{tabular}{lccc}
\hline $\begin{array}{l}\text { What is the hardest thing about losing } \\
\text { weight for you personally? Is it: }\end{array}$ & Frequency & Percent & $\begin{array}{c}\text { Cumulative } \\
\text { Percent }\end{array}$ \\
\hline Having the willpower & 285 & 40.08 & 40.08 \\
Having enough time & 148 & 20.82 & 60.90 \\
Knowing what to do & 28 & 3.94 & 64.84 \\
Paying for healthy food & 50 & 7.03 & 71.87 \\
Taking the trouble to count calories & 77 & 10.83 & 82.70 \\
Doing the physical exercise & 102 & 14.35 & 97.05 \\
Don't know / No opinion & 21 & 2.95 & 100.00 \\
Total & 711 & 100.00 & \\
\hline
\end{tabular}


Table 2

Effect of Lack of Willpower on Body Mass Index, Pooled Sample

\begin{tabular}{|c|c|c|c|c|}
\hline & (1) & (2) & (3) & (4) \\
\hline & Roper Center & Roper Center & BRFSS & BRFSS \\
\hline No willpower & & $\begin{array}{l}0.502 \\
(1.10)\end{array}$ & & \\
\hline Desire but no effort & & & & $\begin{array}{c}0.691 * * * \\
(25.29)\end{array}$ \\
\hline Married & $\begin{array}{l}-0.589 \\
(1.19)\end{array}$ & $\begin{array}{l}-0.988 \\
(1.44)\end{array}$ & $\begin{array}{c}-0.082 * * \\
(2.20)\end{array}$ & $\begin{array}{c}-0.106 * * * \\
(2.86)\end{array}$ \\
\hline Divorced & $\begin{array}{l}-0.028 \\
(0.04)\end{array}$ & $\begin{array}{l}0.856 \\
(0.93)\end{array}$ & $\begin{array}{c}-0.428 * * * \\
(9.66)\end{array}$ & $\begin{array}{c}-0.431 * * * \\
(9.74)\end{array}$ \\
\hline Widowed & $\begin{array}{l}0.096 \\
(0.10)\end{array}$ & $\begin{array}{c}3.052^{* * *} \\
(2.15)\end{array}$ & $\begin{array}{l}-0.088 \\
(1.53)\end{array}$ & $\begin{array}{c}-0.107^{*} \\
(1.85)\end{array}$ \\
\hline Some high school & $\begin{array}{l}1.711 \\
(1.12)\end{array}$ & $\begin{array}{l}2.287 \\
(1.04)\end{array}$ & $\begin{array}{l}-0.011 \\
(0.13)\end{array}$ & $\begin{array}{l}-0.018 \\
(0.21)\end{array}$ \\
\hline High school & $\begin{array}{l}-0.016 \\
(0.01)\end{array}$ & $\begin{array}{l}0.741 \\
(0.36)\end{array}$ & $\begin{array}{c}-0.435 * * * \\
(5.80)\end{array}$ & $\begin{array}{c}-0.443 * * * \\
(5.93)\end{array}$ \\
\hline Some college & $\begin{array}{l}-0.212 \\
(0.15)\end{array}$ & $\begin{array}{l}0.648 \\
(0.31)\end{array}$ & $\begin{array}{c}-0.501 * * * \\
(6.59)\end{array}$ & $\begin{array}{c}-0.504 * * * \\
(6.64)\end{array}$ \\
\hline College & $\begin{array}{l}-1.309 \\
(0.91)\end{array}$ & $\begin{array}{l}-0.700 \\
(0.33)\end{array}$ & $\begin{array}{c}-1.331 * * * \\
(17.30)\end{array}$ & $\begin{array}{c}-1.332 * * * \\
(17.35)\end{array}$ \\
\hline College plus & $\begin{array}{l}-1.932 \\
(1.29)\end{array}$ & $\begin{array}{l}-0.158 \\
(0.07)\end{array}$ & & \\
\hline Age & $\begin{array}{c}0.349 * * * \\
(5.22)\end{array}$ & $\begin{array}{c}0.255^{* *} \\
(2.57)\end{array}$ & $\begin{array}{c}0.340 * * * \\
(76.71)\end{array}$ & $\begin{array}{c}0.337 * * * \\
(76.16)\end{array}$ \\
\hline Age squared & $\begin{array}{c}-0.003 * * * \\
(4.72)\end{array}$ & $\begin{array}{c}-0.003 * * \\
(2.44)\end{array}$ & $\begin{array}{c}-0.003 * * * \\
(73.85)\end{array}$ & $\begin{array}{c}-0.003 * * * \\
(73.30)\end{array}$ \\
\hline Income & $\begin{array}{l}-0.003 \\
(0.91)\end{array}$ & $\begin{array}{l}-0.006 \\
(1.52)\end{array}$ & $\begin{array}{c}-0.017 * * * \\
(31.97)\end{array}$ & $\begin{array}{c}-0.017 * * * \\
(31.69)\end{array}$ \\
\hline Black & $\begin{array}{c}2.012 * * * \\
(3.25)\end{array}$ & $\begin{array}{c}3.197 * * * \\
(3.67)\end{array}$ & $\begin{array}{c}2.110^{* * *} \\
(43.48)\end{array}$ & $\begin{array}{c}2.133 * * * \\
(44.01) \\
\end{array}$ \\
\hline Hispanic & $\begin{array}{l}1.266 \\
(1.62)\end{array}$ & $\begin{array}{c}2.212 * * \\
(2.01)\end{array}$ & $\begin{array}{c}0.521 * * * \\
(9.31)\end{array}$ & $\begin{array}{c}0.535 * * * \\
(9.57)\end{array}$ \\
\hline Other & $\begin{array}{l}-0.109 \\
(0.16)\end{array}$ & $\begin{array}{l}0.340 \\
(0.35)\end{array}$ & $\begin{array}{l}0.028 \\
(0.52)\end{array}$ & $\begin{array}{l}0.038 \\
(0.71)\end{array}$ \\
\hline Urban & $\begin{array}{l}-0.290 \\
(0.84)\end{array}$ & $\begin{array}{c}-1.205 * * \\
(2.57)\end{array}$ & & \\
\hline Male & $\begin{array}{c}1.257 * * * \\
(3.76)\end{array}$ & $\begin{array}{c}1.882^{* * * *} \\
(4.04)\end{array}$ & $\begin{array}{c}0.941 * * * \\
(38.07)\end{array}$ & $\begin{array}{c}0.956 * * * \\
(38.72)\end{array}$ \\
\hline Constant & $\begin{array}{c}18.154 * * * \\
(9.46)\end{array}$ & $\begin{array}{c}21.899 * * * \\
(7.98)\end{array}$ & $\begin{array}{c}19.871 * * * \\
(124.06)\end{array}$ & $\begin{array}{c}19.753 * * * \\
(123.46)\end{array}$ \\
\hline Observations & 979 & 555 & 212,648 & 212,648 \\
\hline
\end{tabular}

Note: Absolute value of $\mathrm{t}$ statistics in parentheses. * Significant at 10\%; ** Significant at 5\%; *** Significant at $1 \%$. Reference categories for marital status, education, and race are single, elementary school or less, and white, respectively. BRFSS regressions include controls for state of residence. 
Table 3

\section{Effect of Lack of Willpower on Body Mass Index, by Gender}

\begin{tabular}{|c|c|c|c|c|}
\hline & \multicolumn{2}{|c|}{ Males } & \multicolumn{2}{|c|}{ Females } \\
\hline & Roper Center & BRFSS & Roper Center & BRFSS \\
\hline No willpower & $\begin{array}{l}1.169^{*} \\
(1.81)\end{array}$ & & $\begin{array}{l}0.189 \\
(0.29)\end{array}$ & \\
\hline Desire but no effort & & $\begin{array}{c}1.152 * * * \\
(30.52)\end{array}$ & & $\begin{array}{c}0.318 * * * \\
(8.39)\end{array}$ \\
\hline Married & $\begin{array}{l}-0.368 \\
(0.39)\end{array}$ & $\begin{array}{c}0.465^{* * *} \\
(9.66)\end{array}$ & $\begin{array}{l}-1.162 \\
(1.19)\end{array}$ & $\begin{array}{c}-0.495 * * * \\
(9.15)\end{array}$ \\
\hline Divorced & $\begin{array}{l}2.292 * \\
(1.72)\end{array}$ & $\begin{array}{l}-0.099 \\
(1.64)\end{array}$ & $\begin{array}{l}0.071 \\
(0.06)\end{array}$ & $\begin{array}{c}-0.767 * * * \\
(12.36)\end{array}$ \\
\hline Widowed & $\begin{array}{l}-0.622 \\
(0.24)\end{array}$ & $\begin{array}{c}0.321 * * * \\
(3.40)\end{array}$ & $\begin{array}{c}3.603 * * \\
(2.00)\end{array}$ & $\begin{array}{c}-0.639 * * * \\
(8.36)\end{array}$ \\
\hline Some high school & $\begin{array}{l}1.794 \\
(0.58)\end{array}$ & $\begin{array}{c}-0.209^{*} \\
(1.87)\end{array}$ & $\begin{array}{l}2.845 \\
(0.91)\end{array}$ & $\begin{array}{l}-0.099 \\
(0.81)\end{array}$ \\
\hline High school & $\begin{array}{l}-0.097 \\
(0.03) \\
\end{array}$ & $\begin{array}{c}-0.227 * * \\
(2.35)\end{array}$ & $\begin{array}{l}1.494 \\
(0.51)\end{array}$ & $\begin{array}{c}-0.792 * * * \\
(7.24)\end{array}$ \\
\hline Some college & $\begin{array}{l}-0.477 \\
(0.17)\end{array}$ & $\begin{array}{c}-0.223 * * \\
(2.27)\end{array}$ & $\begin{array}{l}1.563 \\
(0.53)\end{array}$ & $\begin{array}{c}-0.877 * * * \\
(7.92)\end{array}$ \\
\hline College & $\begin{array}{l}-0.943 \\
(0.32)\end{array}$ & $\begin{array}{c}-0.952 * * * \\
(9.65)\end{array}$ & $\begin{array}{l}-0.132 \\
(0.04)\end{array}$ & $\begin{array}{c}-1.824 * * * \\
(16.21)\end{array}$ \\
\hline College plus & $\begin{array}{l}-1.125 \\
(0.38)\end{array}$ & & $\begin{array}{l}0.741 \\
(0.23)\end{array}$ & \\
\hline Age & $\begin{array}{l}0.116 \\
(0.80)\end{array}$ & $\begin{array}{c}0.281 * * * \\
(46.05)\end{array}$ & $\begin{array}{c}0.301 * * \\
(2.19)\end{array}$ & $\begin{array}{c}0.376 * * * \\
(60.99)\end{array}$ \\
\hline Age squared & $\begin{array}{l}-0.001 \\
(0.90)\end{array}$ & $\begin{array}{c}-0.003 * * * \\
(45.65)\end{array}$ & $\begin{array}{c}-0.003 * * \\
(2.00)\end{array}$ & $\begin{array}{c}-0.003 * * * \\
(57.93)\end{array}$ \\
\hline Income & $\begin{array}{l}-0.002 \\
(0.35)\end{array}$ & $\begin{array}{c}-0.003 * * * \\
(4.38)\end{array}$ & $\begin{array}{l}-0.009 \\
(1.45)\end{array}$ & $\begin{array}{c}-0.030 * * * \\
(37.49) \\
\end{array}$ \\
\hline Black & $\begin{array}{c}2.653^{*} \\
(1.96)\end{array}$ & $\begin{array}{c}0.764 * * * \\
(10.80)\end{array}$ & $\begin{array}{c}3.421 * * * \\
(2.96)\end{array}$ & $\begin{array}{c}2.781 * * * \\
(42.66)\end{array}$ \\
\hline Hispanic & $\begin{array}{l}-0.219 \\
(0.14)\end{array}$ & $\begin{array}{c}0.274 * * * \\
(3.61)\end{array}$ & $\begin{array}{c}3.610^{* * *} \\
(2.35)\end{array}$ & $\begin{array}{c}0.700 * * * \\
(8.92)\end{array}$ \\
\hline Other & $\begin{array}{l}0.267 \\
(0.21)\end{array}$ & $\begin{array}{l}-0.064 \\
(0.92)\end{array}$ & $\begin{array}{l}0.295 \\
(0.21)\end{array}$ & $\begin{array}{l}0.110 \\
(1.43)\end{array}$ \\
\hline Urban & $\begin{array}{l}-0.605 \\
(0.93)\end{array}$ & & $\begin{array}{c}-1.514^{* *} \\
(2.30)\end{array}$ & \\
\hline Constant & $\begin{array}{c}26.983 * * * \\
(7.25)\end{array}$ & $\begin{array}{c}20.989 * * * \\
(95.32)\end{array}$ & $\begin{array}{c}20.530 * * * \\
(5.18)\end{array}$ & $\begin{array}{c}19.880 * * * \\
(89.39)\end{array}$ \\
\hline Observations & 223 & 88,977 & 332 & 123,671 \\
\hline
\end{tabular}

Note: Absolute value of $\mathrm{t}$ statistics in parentheses. * Significant at 10\%; ** Significant at 5\%; *** Significant at $1 \%$. Reference categories for marital status, education, and race are single, elementary school or less, and white, respectively. BRFSS regressions include controls for state of residence. 
Table 4

Effect of Lack of Willpower on Obesity, Pooled Sample

\begin{tabular}{|c|c|c|c|c|}
\hline & $(1)$ & (2) & (3) & (4) \\
\hline & Roper Center & Roper Center & BRFSS & BRFSS \\
\hline No willpower & & $\begin{array}{l}0.082 \\
(0.67) \\
\end{array}$ & & \\
\hline Desire but no effort & & & & $\begin{array}{c}0.017 * * \\
(2.42) \\
\end{array}$ \\
\hline Married & $\begin{array}{c}-0.309 * * \\
(2.09) \\
\end{array}$ & $\begin{array}{c}-0.429 * * \\
(2.35) \\
\end{array}$ & $\begin{array}{c}-0.028 * * * \\
(2.94)\end{array}$ & $\begin{array}{c}-0.028 * * * * \\
(3.00)\end{array}$ \\
\hline Divorced & $\begin{array}{l}-0.226 \\
(1.20)\end{array}$ & $\begin{array}{l}-0.267 \\
(1.12)\end{array}$ & $\begin{array}{c}-0.091 * * * \\
(8.18)\end{array}$ & $\begin{array}{c}-0.091 * * * \\
(8.19)\end{array}$ \\
\hline Widowed & $\begin{array}{l}0.001 \\
(0.00)\end{array}$ & $\begin{array}{l}0.321 \\
(0.89)\end{array}$ & $\begin{array}{l}-0.017 \\
(1.19)\end{array}$ & $\begin{array}{l}-0.018 \\
(1.22)\end{array}$ \\
\hline Some high school & $\begin{array}{l}-0.059 \\
(0.14)\end{array}$ & $\begin{array}{l}0.064 \\
(0.11)\end{array}$ & $\begin{array}{l}0.013 \\
(0.64)\end{array}$ & $\begin{array}{l}0.013 \\
(0.63)\end{array}$ \\
\hline High school & $\begin{array}{l}0.004 \\
(0.01) \\
\end{array}$ & $\begin{array}{l}0.181 \\
(0.33) \\
\end{array}$ & $\begin{array}{c}-0.085^{* * *} \\
(4.67) \\
\end{array}$ & $\begin{array}{c}-0.086 * * * \\
(4.68) \\
\end{array}$ \\
\hline Some college & $\begin{array}{l}-0.203 \\
(0.50) \\
\end{array}$ & $\begin{array}{l}-0.093 \\
(0.17) \\
\end{array}$ & $\begin{array}{c}-0.107 * * * \\
(5.77) \\
\end{array}$ & $\begin{array}{c}-0.107 * * * \\
(5.77)\end{array}$ \\
\hline College & $\begin{array}{l}-0.465 \\
(1.12)\end{array}$ & $\begin{array}{l}-0.266 \\
(0.47)\end{array}$ & $\begin{array}{c}-0.293 * * * \\
(15.43)\end{array}$ & $\begin{array}{c}-0.292 * * * \\
(15.43)\end{array}$ \\
\hline College plus & $\begin{array}{l}-0.576 \\
(1.32) \\
\end{array}$ & $\begin{array}{l}-0.336 \\
(0.58)\end{array}$ & & \\
\hline Age & $\begin{array}{c}0.088 * * * \\
(4.10)\end{array}$ & $\begin{array}{c}0.063^{* *} \\
(2.32) \\
\end{array}$ & $\begin{array}{c}0.068 * * * \\
(56.73)\end{array}$ & $\begin{array}{c}0.068 * * * \\
(56.69) \\
\end{array}$ \\
\hline Age squared & $\begin{array}{c}-0.001 * * * \\
(3.80)\end{array}$ & $\begin{array}{c}-0.001 * * \\
(2.21)\end{array}$ & $\begin{array}{c}-0.001 * * * \\
(55.87)\end{array}$ & $\begin{array}{c}-0.001 * * * \\
(55.83)\end{array}$ \\
\hline Income & $\begin{array}{l}-0.001 \\
(0.89) \\
\end{array}$ & $\begin{array}{c}-0.002 * \\
(1.88)\end{array}$ & $\begin{array}{c}-0.004 * * * \\
(28.59)\end{array}$ & $\begin{array}{c}-0.004 * * * \\
(28.56) \\
\end{array}$ \\
\hline Black & $\begin{array}{c}0.401 * * \\
(2.39)\end{array}$ & $\begin{array}{c}0.534 * * \\
(2.44) \\
\end{array}$ & $\begin{array}{c}0.365 * * * \\
(31.39) \\
\end{array}$ & $\begin{array}{c}0.365^{* * *} * \\
(31.43)\end{array}$ \\
\hline Hispanic & $\begin{array}{l}0.333 \\
(1.54) \\
\end{array}$ & $\begin{array}{l}0.413 \\
(1.48) \\
\end{array}$ & $\begin{array}{c}0.063 * * * \\
(4.47) \\
\end{array}$ & $\begin{array}{c}0.064 * * * \\
(4.49) \\
\end{array}$ \\
\hline Other & $\begin{array}{l}0.079 \\
(0.38)\end{array}$ & $\begin{array}{l}0.064 \\
(0.24)\end{array}$ & $\begin{array}{l}0.018 \\
(1.28)\end{array}$ & $\begin{array}{l}0.018 \\
(1.29)\end{array}$ \\
\hline Urban & $\begin{array}{l}-0.061 \\
(0.59) \\
\end{array}$ & $\begin{array}{c}-0.216^{*} \\
(1.70) \\
\end{array}$ & & \\
\hline Male & $\begin{array}{l}0.059 \\
(0.59) \\
\end{array}$ & $\begin{array}{c}0.342 * * * \\
(2.74)\end{array}$ & $\begin{array}{c}0.035 * * * \\
(5.53)\end{array}$ & $\begin{array}{c}0.035^{* * *} * \\
(5.57)\end{array}$ \\
\hline Constant & $\begin{array}{c}-2.618 * * * \\
(4.49)\end{array}$ & $\begin{array}{c}-1.739 * * \\
(2.35)\end{array}$ & $\begin{array}{c}-1.950 * * * \\
(47.60)\end{array}$ & $\begin{array}{c}-1.953 * * * \\
(47.66)\end{array}$ \\
\hline Observations & 979 & 555 & 212,648 & 212,648 \\
\hline
\end{tabular}

Note: Absolute value of $\mathrm{t}$ statistics in parentheses. * Significant at 10\%; ** Significant at 5\%; *** Significant at $1 \%$. Reference categories for marital status, education, and race are single, elementary school or less, and white, respectively. BRFSS regressions include controls for state of residence. 
Table 5

\section{Effect of Lack of Willpower on Obesity, by Gender}

\begin{tabular}{|c|c|c|c|c|}
\hline & \multicolumn{2}{|c|}{ Males } & \multicolumn{2}{|c|}{ Females } \\
\hline & Roper Center & BRFSS & Roper Center & BRFSS \\
\hline No willpower & $\begin{array}{c}0.474 * * \\
(2.42)\end{array}$ & & $\begin{array}{l}-0.153 \\
(0.91)\end{array}$ & \\
\hline Desire but no effort & & $\begin{array}{c}0.116 * * * \\
(10.78)\end{array}$ & & $\begin{array}{c}-0.067 * * * \\
(7.31)\end{array}$ \\
\hline Married & $\begin{array}{l}-0.355 \\
(1.26)\end{array}$ & $\begin{array}{c}0.083 * * * \\
(5.87)\end{array}$ & $\begin{array}{c}-0.461^{*} \\
(1.82)\end{array}$ & $\begin{array}{c}-0.111 * * * \\
(8.62)\end{array}$ \\
\hline Divorced & $\begin{array}{l}-0.088 \\
(0.23) \\
\end{array}$ & $\begin{array}{c}-0.058 * * * \\
(3.29) \\
\end{array}$ & $\begin{array}{l}-0.386 \\
(1.21)\end{array}$ & $\begin{array}{c}-0.141 \text { *** } \\
(9.69)\end{array}$ \\
\hline Widowed & $\begin{array}{l}-0.516 \\
(0.63)\end{array}$ & $\begin{array}{c}0.068^{* * *} \\
(2.43)\end{array}$ & $\begin{array}{l}0.415 \\
(0.95)\end{array}$ & $\begin{array}{c}-0.121 * * * \\
(6.71)\end{array}$ \\
\hline Some high school & $\begin{array}{l}-0.387 \\
(0.41)\end{array}$ & $\begin{array}{l}-0.006 \\
(0.19)\end{array}$ & $\begin{array}{l}0.297 \\
(0.39)\end{array}$ & $\begin{array}{l}-0.004 \\
(0.15)\end{array}$ \\
\hline High school & $\begin{array}{l}0.117 \\
(0.13)\end{array}$ & $\begin{array}{c}-0.047^{*} \\
(1.70)\end{array}$ & $\begin{array}{l}0.174 \\
(0.24)\end{array}$ & $\begin{array}{c}-0.139 * * * \\
(5.62)\end{array}$ \\
\hline Some college & $\begin{array}{l}-0.420 \\
(0.48)\end{array}$ & $\begin{array}{c}-0.067 * * \\
(2.42)\end{array}$ & $\begin{array}{l}0.024 \\
(0.03)\end{array}$ & $\begin{array}{c}-0.158 * * * \\
(6.28)\end{array}$ \\
\hline College & $\begin{array}{l}-0.189 \\
(0.21)\end{array}$ & $\begin{array}{c}-0.258 * * * \\
(9.14)\end{array}$ & $\begin{array}{c}-0.408 \\
(0.56)\end{array}$ & $\begin{array}{c}-0.349 * * * \\
(13.53)\end{array}$ \\
\hline College plus & $\begin{array}{l}-0.718 \\
(0.79)\end{array}$ & & $\begin{array}{l}-0.078 \\
(0.10)\end{array}$ & \\
\hline Age & $\begin{array}{l}0.029 \\
(0.65)\end{array}$ & $\begin{array}{c}0.064 * * * \\
(33.92)\end{array}$ & $\begin{array}{c}0.085^{* *} \\
(2.34) \\
\end{array}$ & $\begin{array}{c}0.071 * * * \\
(45.68)\end{array}$ \\
\hline Age squared & $\begin{array}{l}-0.000 \\
(0.73)\end{array}$ & $\begin{array}{c}-0.001 * * * \\
(34.23)\end{array}$ & $\begin{array}{c}-0.001 * * \\
(2.17)\end{array}$ & $\begin{array}{c}-0.001 * * * \\
(44.39)\end{array}$ \\
\hline Income & $\begin{array}{l}-0.002 \\
(1.34)\end{array}$ & $\begin{array}{c}-0.002 * * * \\
(7.78)\end{array}$ & $\begin{array}{l}-0.002 \\
(1.32)\end{array}$ & $\begin{array}{c}-0.007 * * * \\
(32.41)\end{array}$ \\
\hline Black & $\begin{array}{c}0.772 * * \\
(2.02)\end{array}$ & $\begin{array}{c}0.184 * * * \\
(9.29)\end{array}$ & $\begin{array}{c}0.478^{*} \\
(1.72)\end{array}$ & $\begin{array}{c}0.444 * * * \\
(30.44)\end{array}$ \\
\hline Hispanic & $\begin{array}{l}-0.087 \\
(0.18) \\
\end{array}$ & $\begin{array}{l}0.026 \\
(1.16)\end{array}$ & $\begin{array}{c}0.659^{*} \\
(1.85)\end{array}$ & $\begin{array}{c}0.087 * * * \\
(4.67)\end{array}$ \\
\hline Other & $\begin{array}{l}0.047 \\
(0.12)\end{array}$ & $\begin{array}{l}0.029 \\
(1.43)\end{array}$ & $\begin{array}{l}0.069 \\
(0.18)\end{array}$ & $\begin{array}{l}0.007 \\
(0.35)\end{array}$ \\
\hline Urban & $\begin{array}{l}-0.090 \\
(0.46)\end{array}$ & & $\begin{array}{c}-0.334^{*} \\
(1.92)\end{array}$ & \\
\hline Constant & $\begin{array}{l}-0.593 \\
(0.52)\end{array}$ & $\begin{array}{c}-2.010 * * * \\
(31.04)\end{array}$ & $\begin{array}{c}-2.134 * * \\
(2.15)\end{array}$ & $\begin{array}{c}-1.850 \text { *** } \\
(34.79)\end{array}$ \\
\hline Observations & 223 & 88,977 & 332 & 123,671 \\
\hline
\end{tabular}

Note: Absolute value of $\mathrm{t}$ statistics in parentheses. * Significant at 10\%; ** Significant at 5\%; *** Significant at $1 \%$. Reference categories for marital status, education, and race are single, elementary school or less, and white, respectively. BRFSS regressions include controls for state of residence. 
Figure 1: Percent of Respondents Who Would Like to Lose Weight, By Weight Category

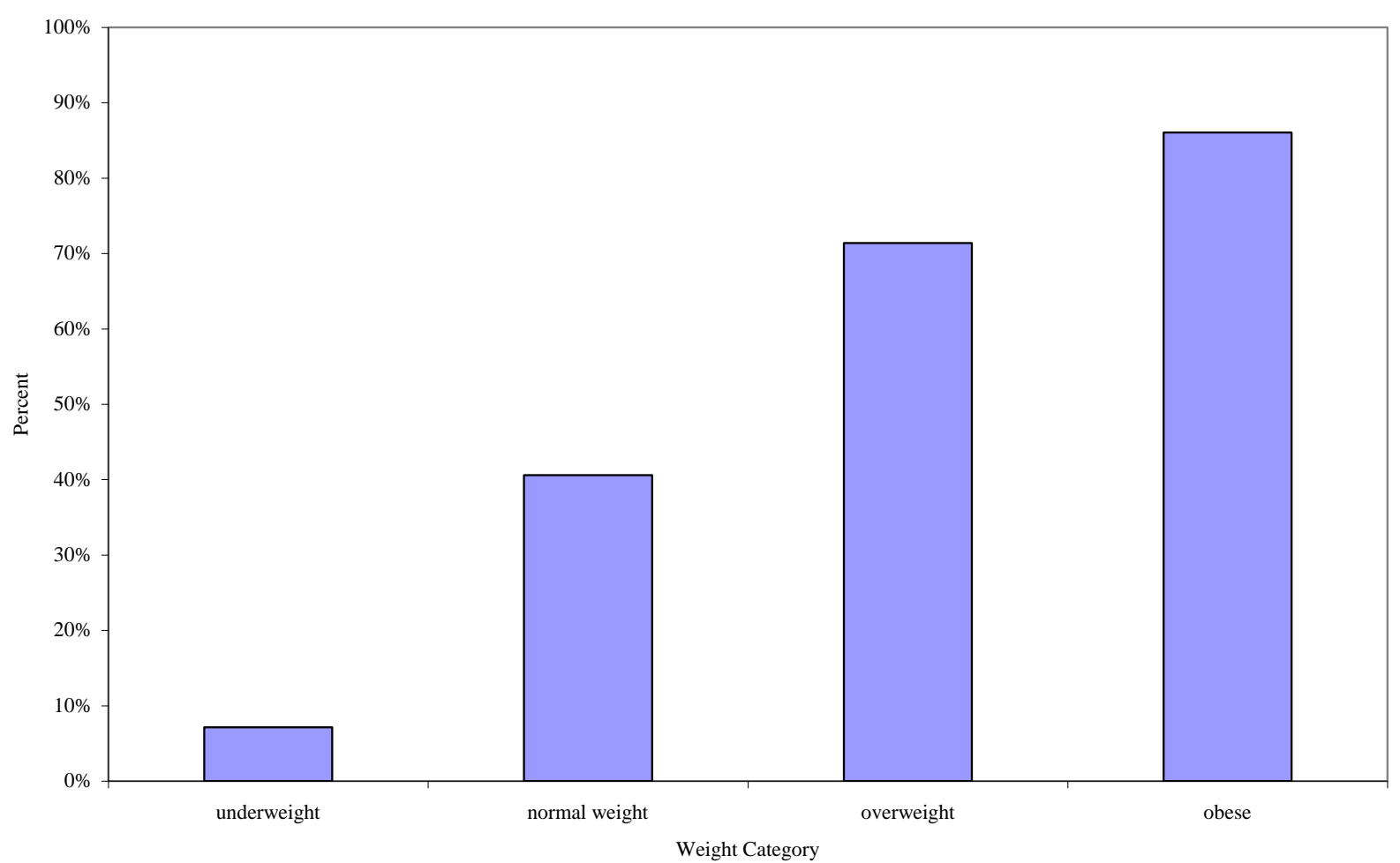


Figure 2: Percent of Respondents Wanting to Lose Weight Who Struggle with Willpower, By Weight Category

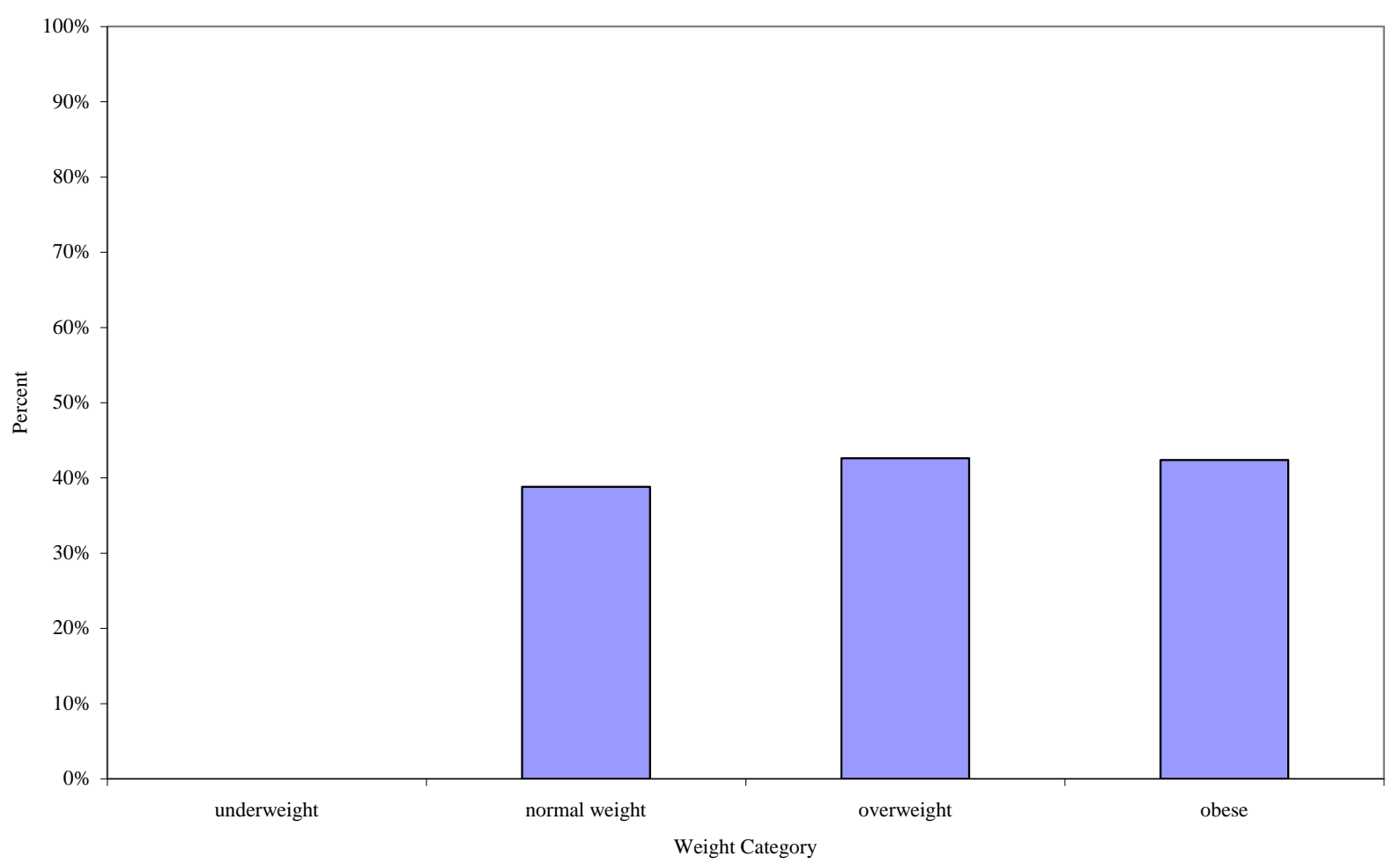


Figure 3: Percent of Respondents Who Perceive Themselves as Somewhat Overweight or Very Overweight, By Weight Category

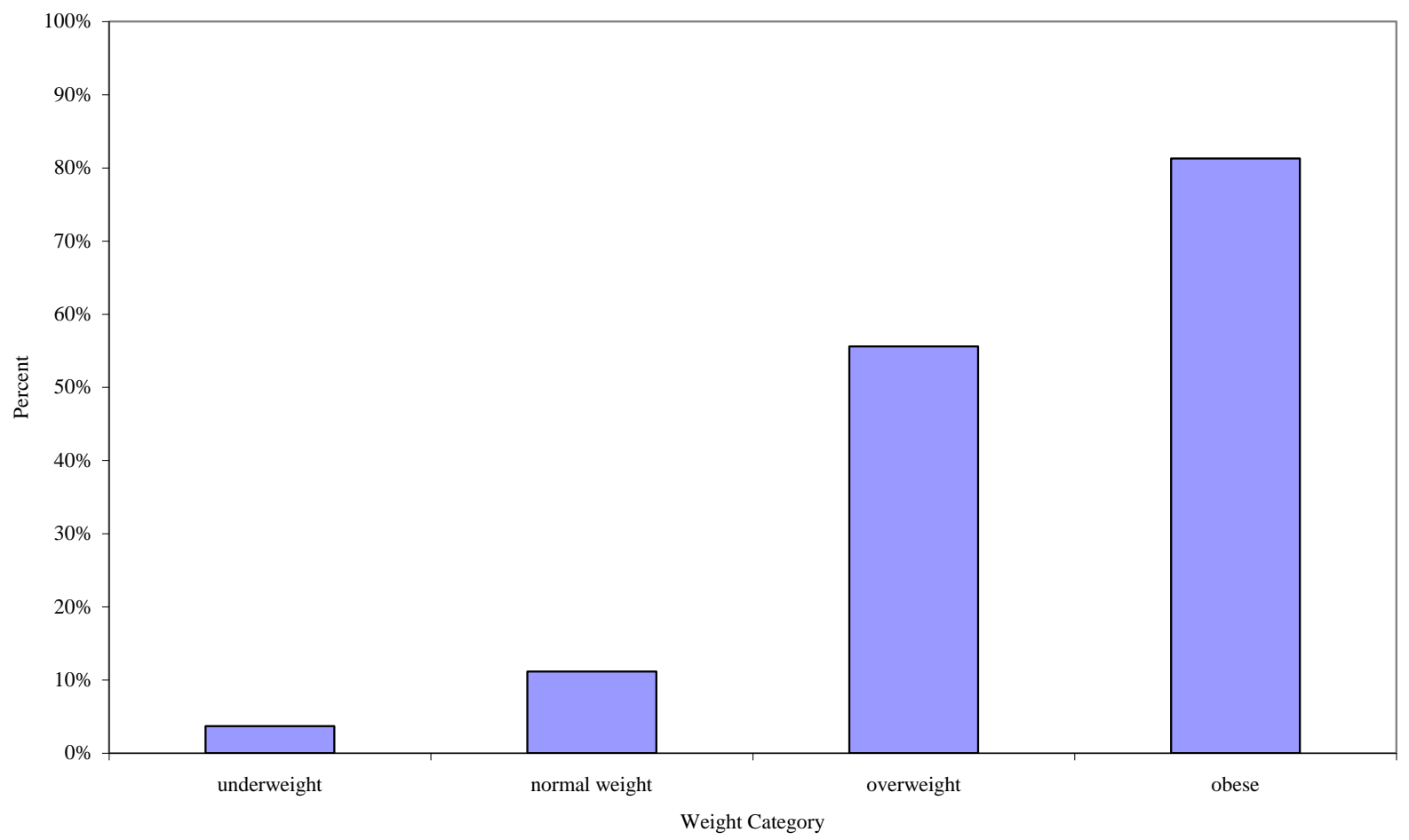

